\title{
FOCUS ON THE
}

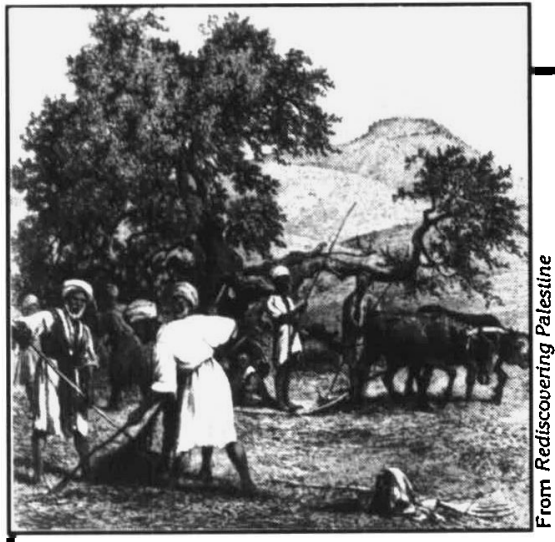

\section{Afghanistan}

The Soviet Invasion and the Afghan Response M. HASSAN KAKAR

"An outstanding account of a complex and interesting phase of modern Afghanistan history. . . . A fascinating and absorbing analysis ... exhaustive and most valuable." - -Vartan Gregorian,

President, Brown University $\$ 35.00, \$ 28.00$ cloth

\section{The Republic of Armenia}

Volume 3: From London to Sèvres, FebruaryAugust 1920

Volume 4: Between Crescent and Sickle: Partition and Sovietization RICHARD G. HOVANNISIAN With these two volumes, Hovannisian completes his definitive history of the first independent Armenian state in modern times and provides the basis for comparison with the new Armenian republic established in 1991.

Each volume: $\$ 45.00, \$ 35.00$ cloth, illustrated
MIDDLE EAST

\section{Rediscovering Palestine}

Merchants and Peasants in Jabal Nablus, 1700-1900

\section{BESHARA DOUMANI}

This book paints an intimate and vivid portrait of Palestinian society on the eve of modernity. Doumani offers a major revision of standard interpretations of Ottoman history by investigating the ways in which urban-rural dynamics in a provincial setting appropriated and gave meaning to the larger forces of Ottoman rule and European economic expansion.

$\$ 50.00, \$ 40.00$ cloth, $\$ 20.00, \$ 15.95$ paper, illustrated

\section{Men, Women, and God(s)}

Nawal El Saadawi and Arab

Feminist Poetics FEDWA MALTI-DOUGLAS

"An impressive and erudite book that offers significant interpretations of the work of one of the most important writers of the international community."

-Susan Jeffords, University of Washington A Centennial Book, $\$ 45.00, \$ 35.00$ cloth, $\$ 17.00$. \$13.95 paper

\section{Human Rights and Reform}

Changing the Face of North

African Politics

\section{SUSAN WALTZ}

In this first systematic comparative analysis of North African politics in more than a decade, Waltz explores the ability of society, including Islamist forces, to challenge the powers of states. $\$ 45.00, \$ 32.00$ cloth, $\$ 16.00, \$ 11.95$ paper

At bookstores or order 1-800-822-6657 (US), (+243)829121 (UK).

UNIVERSITY OF CALIFORNIA PRESS 


\title{
THE OXFORD ENCYCLOPEDIA OF THE MODERN ISLAMIC WORLD
}

\author{
EDITED BY JOHN L. ESPOSITO, \\ Center for Maslim-Christian Understanding, Georgetown University
}

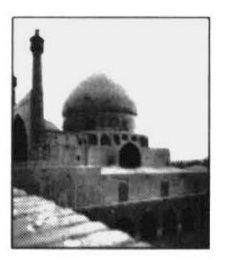

"Presenting a rounded picture of a subject about which Americans hear only the extremes, The Oxford Encyclopedia of the Modern Iolamic World is an important purchase for academic and public libraries."

-Booklist/Reference Books Bulletin.

"A valuable reference for every sort of reader....Well edited, clear, and jargon free....Highly recommended for both academic and public libraries."

- Library Journal

This is the first comprehensive encyclopedia dedicated to the institutions, religion, politics, and culture in Muslim societies throughout the world. Placing particular emphasis on the 19 th and 20 th centuries, over 750 articles by a group of international scholars focus on the Islamic dimension of the Muslim experience in recent history. Background articles ground the information in its historical context and ensure continuity.
Unlike more limited explorations of Islam, this work looks at Muslim societies in the Arab heartland as well as in South and Southeast Asia, and even in Europe and the Americas. Thus it offers extensive comparative and systematic analyses of Islamic beliefs, institutions, movements, practices, and peoples on an international scale.

Unique in its focus on the modern Islamic world, it is an invaluable reference for anyone concerned with Islam: scholars and students, government and media analysts who increasingly require an understanding of

the Muslim world, and interested lay readers who are becoming more and more familiar with Islamic politics and culture.

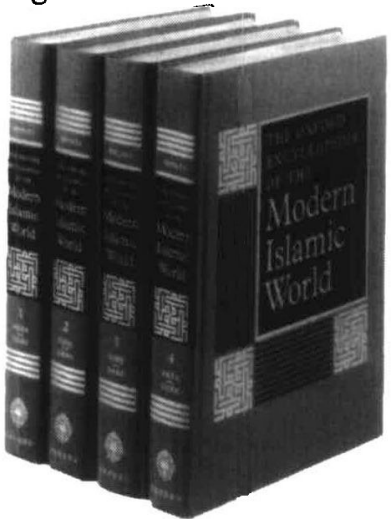

1995 1920 PAGES; 50 ILLUS. $\$ 395.00$ for tbe 4.VOLUME SET

\section{OXFORD LINIVERSITY' FRESS}

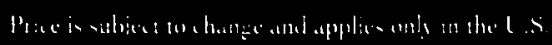

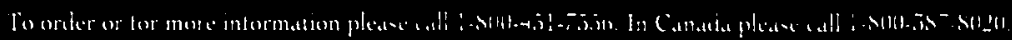




\section{THE BOOK IN THE ISLAMIC WORLD}

THE WRITTEN WORD AND COMMUNICATION IN THE MIDDLE EAST

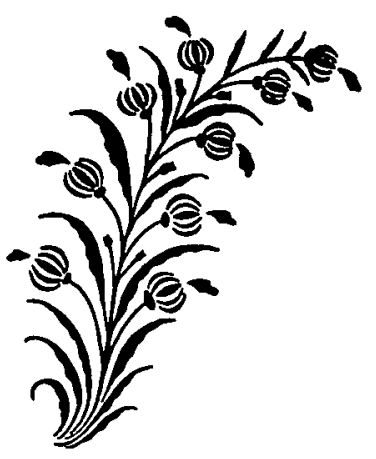

Published jointly with the Library of Congress, this is an illustrated history of the book and the written word in the Islamic world.

305 pgs. • illustrated $\$ 19.95$ paperback ISBN 0-7914-2474-X

\section{EDITED BY GEORGE N. ATIYEH}

“...sound, persuasive, interesting, and compelling. ... a delight to the eyes as well as to the mind."

- Charles E. Butterworth, University of Maryland, College Park

This volume brings together studies on the book as an intellectual entity and as a vehicle of cultural development in the Islamic world. Written by a distinguished group of scholars-Muhsin Mahdi, Jacques Berque, Franz Rosenthal, Seyyed Hossein Nasr, Annemarie Schimmel, Wadād al-Qāợi, Ramzi Baalbaki, Șalāh al-Din al-Munajjid, David A. King, Priscilla P. Soucek and Filiz Çağman, Geoffrey Roper, George N. Atiyeh, Dale F. Eickelman, and Michael W. Albin-it examines and reflects upon this unique tool of communication not as a physical artifact but as a manifestation of the aspirations, values, and wisdom of Arabs and Muslims in general.

Available from your local bookseller or through

State University of New York Press • clo CUP Services • PO Box 6525 Ithaca, NY 14851 1 1-800-666-2211

Orders must be prepaid and include $\$ 3$ shipping/handling for US and Canadian orders, and $\$ 4$ shipping/handling for foreign orders.

NY State residents, add $8 \%$ sales tax. MasterCard, VISA, AMEX, Discover accepted. Make checks payable to SUNY Press. 


\section{The Encyclopaedia of Islam (New Edition)}

\section{Prepared by a Number of Leading Orientalists Under the Patronage of the International Union of Academies}

The Encyclopaedia of Islam (New Edition) sets out the present state of our knowledge of the Islamic World. It is a unique and invaluable reference tool, an essential key to understanding the world of Islam, and the authoritative source not only for the religion, but also for the believers and the countries in which they live.

'...The closest parallel is the $\mathrm{I} I$ th edition of the Encyclopaedia Britannica. In brief, this is one of the great scholarly surveys of learning produced in the 2oth century... simply essential for any kind of cross-cultural educational pursuit...'

Guy Gran, World Development, Vol. I7, No. 4, 1989 .

'...belongs in all academic libraries where courses on the Islamic world are taught, and in all major public libraries.'

David L. White, $A R B A$, 1994.

'...no large library should be without it...' Mohammad Shoeb Nomani, librarian of the King Fahd University, Dhahran, Arab News, 1988.

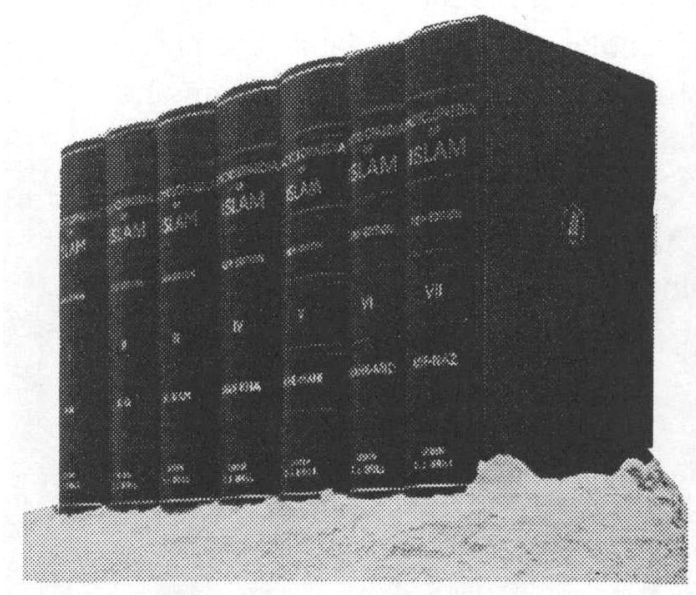

\section{Available Now: Volume VIII}

- I995. (I056 pp. richly illustrated)

- ISBN 9004098348

- Bound NLG 787.50/Uss 508.25

- Price for Subscribers: NLG 682.50/US\$ 440.50

Call for more information: $+31(0) 71-312624$

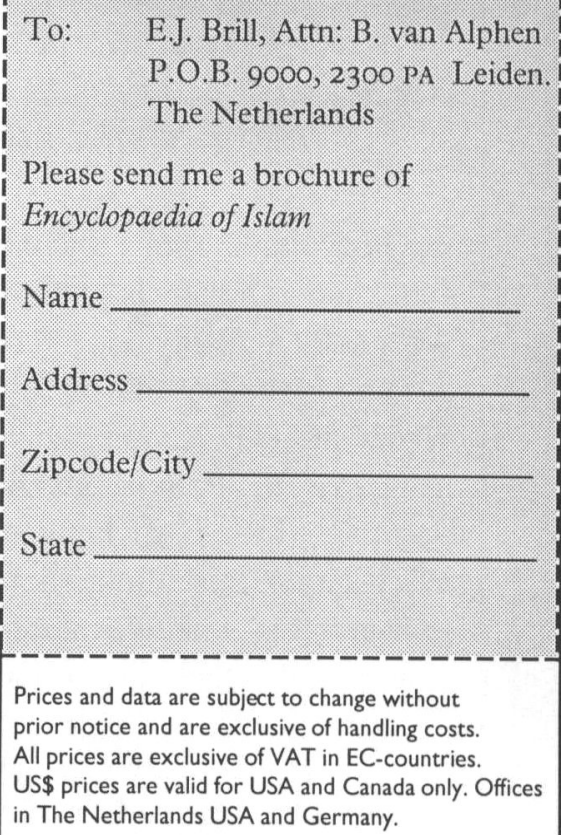

Prices and data are subject to change without prior notice and are exclusive of handling costs. All prices are exclusive of VAT in EC-countries.

US\$ prices are valid for USA and Canada only. Offices in The Netherlands USA and Germany. 


\section{NEW FROM CAMBRIDGE}

\section{Under This Blazing Light} Amos $\mathrm{Oz}$

Nicholas de Lange, Translator

"Under This Blazing Light by Amos $\mathrm{Oz}$ is a wondrous collection of essays that brilliantly reveal to us the heart and mind of one of the great writers of our time."

- Chaim Potok

"Adapted from articles, interviews, and lectures from the 1960s and 70s, this is a provocative collection on Israeli society by one of the country's foremost novelists.... Oz captivates the reader with his elegantly poetic voice."

- Kirkus Reviews

44367-9 Hardback \$19.95

\section{Islamic Society and}

\section{State Power in Senegal}

Disciples and Citizens in Fatick

\section{Leonardo A. Villalón}

While Islamic political groups are often accused of destabilizing African states, Villalón argues that these brotherhoods have played a crucial part in making Senegal one of the most stable and democratic of African countries. Focusing on a regional administrative center, he combines a detailed account of grassroots politics with an analysis of national and international political forces. African Studies Series 80

46007.7 Hardback \$59.95

\section{An Introduction to Islam David Waines}

Islamic theology, sacred law, and mysticism are thoroughly explored, from Meccan origins fourteen centuries ago to the present day, in this account of the beliefs and practices of Muslims. The book reveals how they have continually attempted to renew the values of their faith in the face of internal and external challenges.

41880-1 Hardback \$49.95

\section{Women, Property and Islam}

Palestinian Experiences, 1920-1990

\section{Annelies Moors}

According to Islamic law, women are entitled to inherit property, receive a dowry at marriage, and manage their own income. This study of different Palestinian women reveals the circumstances under which they can actually claim property rights and when they are prevented from doing so.

Cambridge Middle East Studies 3

$\begin{array}{lll}47497-3 & \text { Hardback } & \text { about } \$ 59.95 \\ 48355-7 & \text { Paperback } & \text { about } \$ 19.95\end{array}$

\begin{tabular}{l} 
Now in paperback... \\
Byzantium and the \\
Early Islamic Conquests \\
Walter E. Kaegi \\
"It is good to see military history written \\
competently by someone who knows the \\
sources well and, what is more, has visited \\
the sites of the major conflicts; Kaegi is good \\
on the importance of landscape, strategy \\
and confusion in deciding the outcome.... \\
[A] robust approach..." \\
- Times Literary Supplement \\
48455-3 Paperback \$24.95 \\
Water and Power \\
The Politics of a Scarce Resource in the \\
Jordan River Basin \\
Miriam R. Lowi \\
"Although there have been a number of \\
studies of the Jordan River dispute, none \\
interweaves analysis of the terms of that \\
dispute with the larger Arab-Israeli conflict \\
as successfully as this one." \\
- Social \& Behavioral Sciences \\
Cambridge Middle East Library $\mathbf{3 I}$ \\
55836-0 Paperback about \$19.95 \\
\hline
\end{tabular}




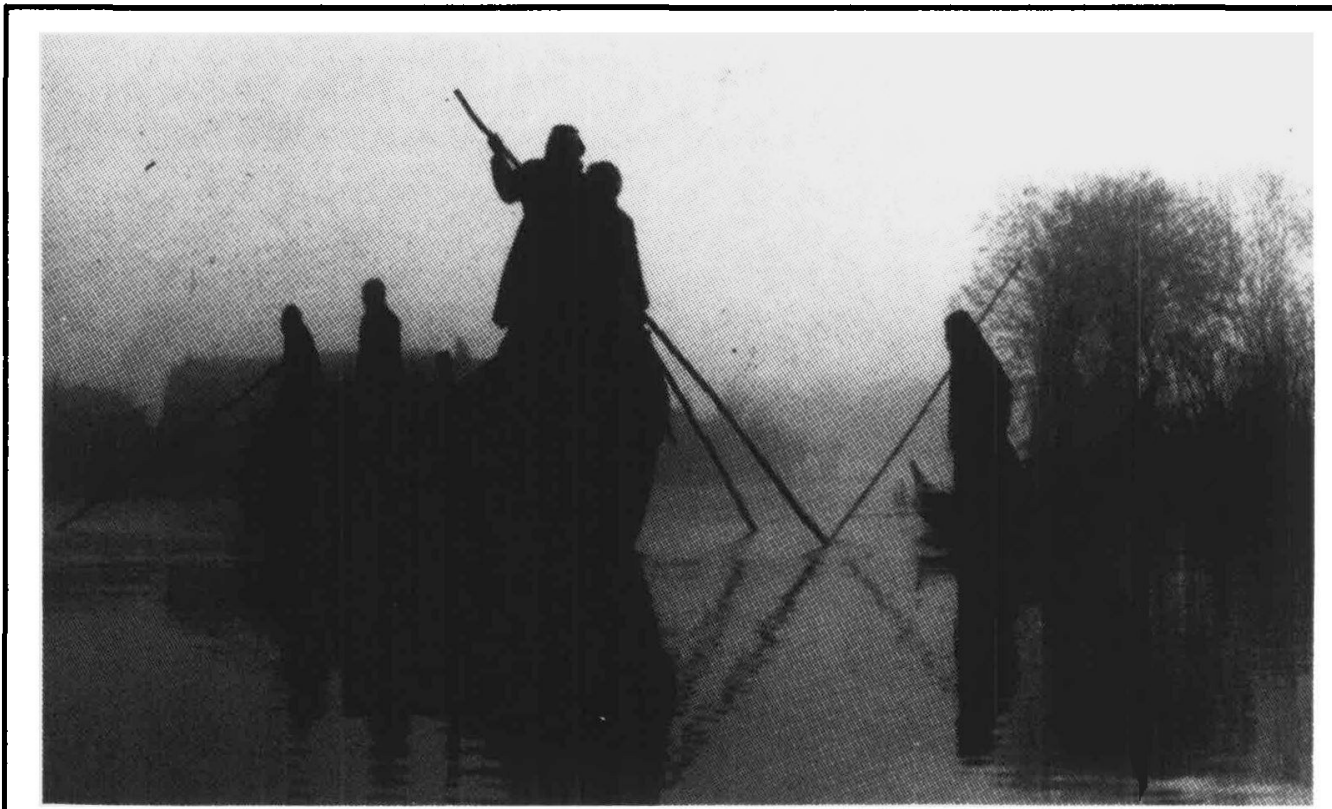

\section{Between Muslim and Jew}

The Problem of Symbiosis under Early Islam

\section{STEVEN M. WASSERSTROM}

Steven Wasserstrom undertakes a detailed analysis of the "creative symbiosis" that existed between Jewish and Muslim religious thought in the eighth through tenth centuries. Wasserstrom brings the disciplinary approaches of religious studies to bear on questions that have been examined previously by historians and by specialists in Judaism and Islam. Throughout, Wasserstrom expands on the work of social and political historians to include symbolic and conceptual aspects of interreligious symbiosis.

"This book will influence all future work on the subject." -William M. Brinner, UC-Berkeley

"A work of high quality and originality ... provocative in the best sense."

- Michael G. Morony, UCLA

Cloth: \$45.00 ISBN 0-691-03455-9 Available now

\section{New in paperback The Shilis of Iraq YITZHAK NAKASH}

Yitzhak Nakash provides a rich historical background for understanding the place of the Shi' is in today's Sunnidominated Iraq. This is the first comprehensive work on the Shi' is of Iraq.

"This is a superb study of Iraq's Shia majority. Based on remarkable scholarship, the book brings to life a whole political community that has often been seen as a mere appendage of the larger Shia population in Iran. ... This study is a potent reminder of the power of the modern state to shape and control even such basic social phenomena as religious identity and its expression."

-Foreign Affairs

"Nakash's account of the process of community formation in Iraq has fascinating implications for modern Middle Eastern history."

-The Times Literary Supplement

Now in paper: \$16.95 ISBN 0-691-00643-1 Available January 1996

\section{Princeton University Press}

AVAILABLE FROM YOUR BOOKSELLER OR DIRECTLY FROM THE PUBLISHER: (609) 883-1759 U.S. (1243) 779777 U.K.JUROPE WORLD WIDE WEB SITE: HTTP: IIAAUP.PUPRESS.PRINCETON.EDUIPURRESS 


\section{ENGLISH TRANSLITERATION SYSTEM CONSONANTS}

Column Headings: A $=$ Arabic, $\mathrm{P}=$ Persian, $\mathrm{OT}=$ Ottoman Turkish, $\mathrm{MT}=$ Modern Turkish

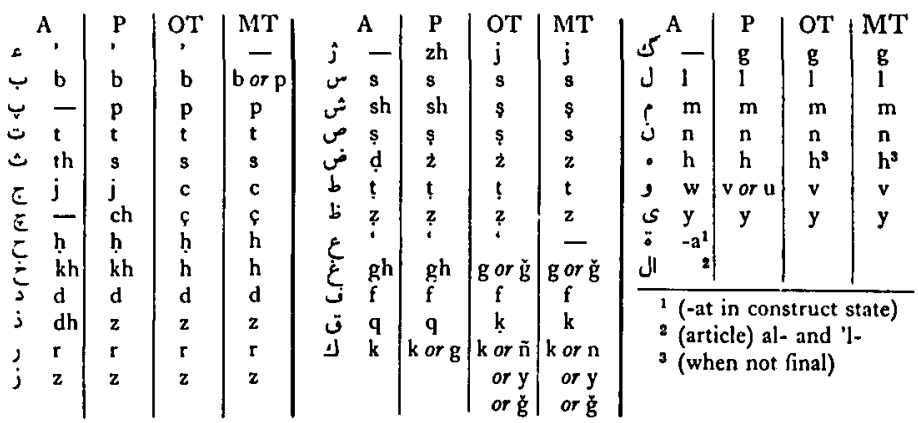

\section{VOWELS}

ARABIC AND PERSIAN

Long I or is à

$$
\rightarrow \text { ù }
$$$$
\text { s i }
$$

Doubled $\quad=$ iyy (final

, uww (final

form $\bar{u}$ ), etc.

Diphthongs , au or aw

$$
\varsigma^{-} \text {ai or ay }
$$

Short

OTTOMAN TURKISH MODERN TURKISH

$\left.\begin{array}{c}\bar{a} \\ \dot{u} \\ i\end{array} \begin{array}{l}\text { words of Arabic } \\ \text { and Persian } \\ \text { origin only }\end{array}\right\} \begin{gathered}\hat{a} \\ \bar{u} \\ \bar{i}\end{gathered}$

iy (final

iy (final form i)

form i)

uvv

uvv

ev ev

ey

a or e

u or ü

ey

, $-\mathbf{u}$

o or $\ddot{0}$

or i

a or

u or ü

o or ö

$=-\mathrm{i}$

I or i 


\section{INTERNATIONAL JOURNAL OF MIDDLE EAST STUDIES}

\section{Contributions and Editorial Correspondence}

Send article submissions to the Editorial Office (address on inside front cover). Articles submitted to the journal should not be, or have been, submitted elsewhere. Books for review should also be sent to the Editor for forwarding to the Book Review Editors. Unsolicited book reviews cannot be accepted for publication.

\section{Manuscript Preparation and Style}

General. An article must be in English, should not exceed 40 typewritten pages (including main text, notes, tables, and figure captions), and should be typed on $81 / 2 " \times 11^{\prime \prime}$ or A4 white bond paper with ample margins on all sides. The entire manuscript-including notes, tables, and references-must be typed double-spaced and numbered consecutively. Title and author's name should be centered at the top of the first text page. Institutional affiliation and location should appear at the bottom of the last text page. The Editor may find it necessary to return manuscripts for reworking or retyping that do not conform to these requirements.

Text. Use a 5-character paragraph indent. Avoid hyphenating words at the end of lines. Do not use desk-top publishing features (e.g., right margin justification or bold and italic typefaces). Block indent long quotations (more than 50 words). Never cross-reference.

Endnotes and References. Notes must be numbered consecutively throughout the text, typed double-spaced in paragraph style, and grouped together as a unit following the text. Footnotes at the bottom of the text page are not permitted. Any acknowledgment of grant support, substantial assistance, etc., should be typed as an Author's Note above the first note. Provide the full name of the author as it appears on the publication. All titles in non-Roman alphabets (Arabic, Cyrillic, etc.) must be transliterated. Foreign titles in Roman alphabets should be capitalized as they would be in that particular language. An English translation of nonstandard language titles should be provided in parentheses after the title. The style of note citations should conform with the following examples:

'Stanford J. Shaw, History of Ottoman Empire and Modern Turkey, 2 vols. (New York: Cambridge University Press, 1977), Reform, Revolution and Republic: The Rise of Modern Turkey 1808-1975, 2:3-6.

${ }^{2}$ Jamil M. Abun-Nasr, A History of the Maghrib in the Islamic Period, 3rd ed. (New York: Cambridge University Press, 1987), 10.

${ }^{3}$ Howard Crane, trans. and ed., Risāle-i Mi māríyye: An Early-Seventeenth-Century Ottoman Treatise on Architecture, Studies in Islamic Art and Architecture 1 (Leiden: E. J. Brill, 1987), 71.

${ }^{4}$ Martin Rein and Donald Schon, "Frame-Reflective Policy Discourse," in Social Sciences and Modern States, ed. Peter Wagner, Carol Hirschon Weiss, Björn Wittrock, and Hellmut Wollman (New York: Cambridge University Press, 1991), 262-89.

sClifford Geertz, "Toutes Directions: Reading the Signs in an Urban Sprawl," International Journal of Middle East Studies 21 (August 1989): 291-306.

When references to the same work follow without interruption use ibid. When notes to the same work follow after interruption, use the author's last name and a shortened title of the book or article. Do not use op. cit.:

${ }^{6}$ Shaw, History of Ottoman Empire, 2:6.

I'Ibid., 1:10-52.

As a less-preferred alternative, authors may use the social science method of citation. In the text, cite author and year in parentheses. In the reference section, provide the full citation: author's full name, title, city of publication, publisher, and year. IJMES does not publish bibliographies.

Foreign Words and Transliteration. All Arabic words found in an unabridged dictionary (e.g., ulema, sheikh, qadi, Sunni, $\mathrm{Shi}{ }^{i}$, mihrab, minbar, madrasa, masjid, jami ${ }^{c}$, hadith, suq) should be treated as English words, that is, not underlined and without diacriticals. Contemporary names and places should be spelled as they are found in such standard publications as the New York Times. All other transliterated words and phrases should be underlined and all their diacriticals included throughout the text. Be sure to distinguish between the hamza, 'ayn, and the apostrophe in the text. No diacritical marks other than the hamza and the ${ }^{c}$ ayn should appear in any proper names (e.g., names of people, dynasties, places) and names of well-known literary works (Qur'an, Shahnama), except: works written in Arabic, Persian, and Ottoman Turkish and cited in transliteration in the notes must include diacriticals for both author and title.

Transliteration System. All non-Roman alphabets must be transliterated, and authors are responsible for the consistency and accuracy of their transliterations. For Arabic and Persian, IJMES uses the modified Encyclopaedia of Islam system: $q a f=\mathrm{q}$ not $\mathrm{k} ; \mathrm{jim}=\mathrm{j}$ not $\mathrm{dj}$; roman double-letter equivalents are not underlined; the $l$ of $a l$-is not assimilated to the following consonant; ta marbuta is rendered $a$ not $a h$; the adjectival -ya followed by ta marbuta is rendered -iyya. Except at the beginning of an English sentence or endnote, only proper names are capitalized. For Ottoman Turkish, use either the Encyclopaedia of Islam system or modern Turkish orthography. For treatment of common Turkish words, such as medrese, turbe, etc., follow the rules on anglicizing Arabic and Persian words.

Dates. IJMES does not use double dating. Use common era (A.D.) dates only, unless quoting from an original source, in which case use the date as quoted (hijra, solar, etc.) with the common-era equivalent in parentheses.

Tables and Figures. Tables and figures must be cited in the text, e.g., (see Table 1). They should be numbered consecutively in arabic numbers, captioned, and appear as a unit following the notes section. They cannot be interspersed in the text. Diagrams must be professionally rendered or computer generated; details should be large enough to remain legible at $50 \%$ reduction. Below-standard artwork will be returned to the author for replacement. All artwork must be numbered and labeled with the author's name and article title. For halftones or other illustrations, consult the editor.

\section{Publishing Information}

Production. The publisher reserves the right to copyedit manuscripts to conform to the journal's style, which follows the rules found in the Chicago Manual of Style. Spelling will be edited to conform to American usage. More substantial editing will be returned to the author for approval before publication.

The lead author will receive one set of proofs for the correction of typographical or factual errors only. No rewriting will be allowed in the proof stage. Authors must return the material to the editorial office within $\mathbf{4 8}$ hours of receipt or approval will be assumed.

Offprints. The lead author of an article (but not bookreview) will receive 50 free offprints of the article. Addjtional offprints may be purchased if ordered at the proof stage. Orders received after the issue is printed are subject to a $50 \%$ reprint surcharge.

Copyright and Originality. Submission of an article implies that it has not been simultaneously submitted or previously published elsewhere. Authors are responsible for obtaining permission to publish any material under copyright. Contributors will be asked to assign their own copyright, on certain conditions, to Cambridge University Press. 
(Contents continued)

Literature and Art

Sheila S. Blair and Jonathan M. Bloom, The Art and Architecture of Islam 1250-1800 (Caroline Williams)

Simin Daneshvar, Sutra and Other Stories (G. Michael Wickens)

$527-528$

Olga M. Davidson, Poet and Hero in the Persian Book of Kings (G. Michael Wickens)

Allen Douglas and Fedwa Malti-Douglas, Arab Comic Strips: Politics of an Emerging Mass Culture (David M. Mednicoff)

Thomas Emil Homerin, From Arab Poet to Muslim Saint: Ibn al-Farid, His Verse and His Shrine (Todd Lawson)

Hanna Mina, Fragments of Memory: A Story of a Syrian Family (John Maier)

THA ${ }^{C}$ ALIBI, La beauté est le gibier des coeurs: anthologie de paroles et maximes; OdETTE PETIT AND WANDa VoIsin, La poésie arabe classique: études textuelles; OdetTE Petit AND Wanda VoIsIN, Abu Firas: Chevalier poète (Ferial J. Ghazoul) 


\section{CONTENTS}

From the Editor

Articles

Paul Dresch and Bernard Haykel Stereotypes and Political Styles: Islamists and Tribesfolk in Yemen

Palmira Brummett Dogs, Women, Cholera, and Other Menaces in the Streets: Cartoon Satire in the Ottoman Revolutionary Press, 1908-11

Raphael Cohen-Almagor Cultural Pluralism and the Israeli Nation-Building Ideology

Kenneth M. Cuno Joint Family Households and Rural Notables in 19th-Century Egypt

$485-502$

Book Reviews

Islam

Richard W. Bulliet, Islam: The View from the Edge (Said Amir Arjomand)

MelHem ChoKR, Zandaqa et Zindiqs en Islam au second siècle de l'Hégire (Mahmood Ibrahim)

H. T. NoRris, Islam in the Balkans: Religion and Society between Europe and the Arab World (Feroz Ahmad)

Arab World

Anton Escher and Eugen Wirth, with Frank Meyer and Carmella Pfaffenbach, Die Medina von Fes. Geographische Beiträge zur Persistenz und Dynamik, Verfall und Erneuerung einer traditionellen islamischen Stadt in handlungstheoretischer Sicht (Peter Von Sivers)

ROBERT E. LoONEY, Manpower Policies and Development in the Persian Gulf Region (Abdullah Juma Al-Haj)

Israel and Arab-Israeli Conflict

Donna Robinson Divine, Politics and Society in Ottoman Palestine: The Arab Struggle for Survival and Power (Judith Mendelsohn Rood)

IAN S. Lustick, Unsettled States/Disputed Lands: Britain and Ireland, France and Algeria, Israel and the West Bank-Gaza (Baruch Kimmerling)

Turkey

KAREN BARKEY, Bandits and Bureaucrats: The Ottoman Route to State Centralization (Amy Singer)

A. L. MACFIE, The Straits Question, 1908-36 (Erik Goldstein)

Iran and Central Asia

Peter Christensen, The Decline of Iranshahr: Irrigation and Environments in the History of the Middle East, 500 B.C. to A.D. 1500 (Richard W. Bulliet)

Moshe Gammer, Muslim Resistance to the Tsar. Shamil and the Conquest of Chechnia and Daghestan (Peter B. Golden)

Annabelle Sreberny-Mohammadi and Ali Mohammadi, Small Media, Big Revolution: Communication, Culture, and the Iranian Revolution (Majid Tehranian)

(Contents continued on inside back cover)

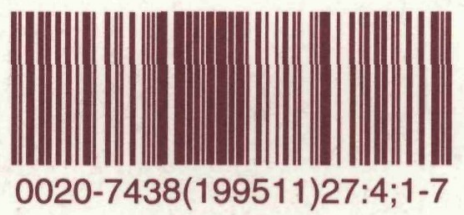

